\title{
Specific accumulation of technetium-99m radiolabelled, negative liposomes in the inflamed paws of rats with adjuvant induced arthritis: effect of liposome size
}

\author{
W G LOVE, ${ }^{12}$ N AMOS, ${ }^{2}$ I W KELLAWAY, ${ }^{1}$ AND B D WILLiAMS \\ From the ${ }^{I}$ Pharmacy Department, University of Wales Institute of Science and Technology (UWIST), Cardiff; \\ and the ${ }^{2}$ Rheumatology Department, University of Wales College of Medicine (UWCM), Cardiff
}

SUMMARY Technetium-99m labelled, negatively charged liposomes accumulate in the inflamed tissue of rats with adjuvant induced arthritis. Up to 10 times more liposome accumulation was seen in inflamed paws than in paws of control rats, and this represented $5.3 \%$ of the injected liposome dose. The accumulation of liposomes in inflamed tissue was directly related to the liposome size, the maximal accumulation occurring with liposomes less than $100 \mathrm{~nm}$ in diameter.

Liposomes are microscopic vesicles composed of concentric phospholipid bilayers encapsulating aqueous compartments. ${ }^{1}$ They are taken up by the cells of the reticuloendothelial system and after intravenous injection are found mainly in the phagocytic cells of the liver, spleen, and bone marrow. Investigators have exploited the natural targeting of radiolabelled liposomes to phagocytic cells in order to identify inflammatory tissue produced in response to bacterial infection. ${ }^{2}$ Accumulation of technetium-99m $\left({ }^{99 m} \mathrm{Tc}\right)$ labelled liposomes occurs in the joints of patients with rheumatoid arthritis and scintigraphy is capable of distinguishing between active and inactive inflammation. ${ }^{3}$ These observations in patients with rheumatoid arthritis, although highlighting the potential use of liposomes in either monitoring disease activity or selective drug targeting, leave unanswered important questions which relate to the stability of the isotope on the liposome surface, the optimal size for localisation in inflammatory tissue, and the quantities of liposomes which accumulate in inflamed tissue. We have attempted to address these questions by determining the behaviour and distribution of ${ }^{99 \mathrm{~m}} \mathrm{Tc}$ labelled, negative liposomes in the adjuvant induced arthritis model in the rat.

\section{Materials and methods}

Egg phosphatidylcholine about $90 \%$ grade was

Accepted for publication 30 June 1988.

Correspondence to Dr W G Love, Rheumatology Department, University of Wales College of Medicine, Cardiff CF4 4XW. purchased from BDH (UK) and purified by a column separation technique. ${ }^{4}$ Phosphatidic acid was purchased from Sigma (UK) and cholesterol from BDH (UK). Sodium iodide $\left({ }^{125} \mathrm{I}\right)$ and sodium chromate $\left({ }^{51} \mathrm{Cr}\right)$ were obtained from Amersham (UK), as was ${ }^{99 \mathrm{~m}} \mathrm{TcO}_{4}^{-}$via a sterile ${ }^{99 \mathrm{~m}} \mathrm{Tc}$ generator.

Sprague-Dawley rats were obtained from Tuck and Sons Ltd (UK), Mycobacterium butyricum from Difco Laboratories (Detroit), and heavy paraffin oil from Sigma (UK).

ADJUVANT INDUCED ARTHRITIS MODEL IN THE RAT

Female Sprague-Dawley rats weighing $200 \mathrm{~g}$ were injected intradermally with $100 \mu$ l of heavy paraffin oil containing $1 \mathrm{mg}$ of finely ground, heat killed $M$ butyricum, an adaptation from the original method of Pearson. ${ }^{5}$ Arthritis developed 10-14 days after injection, and the severity of inflammation was given an arthritic score using a grading method. ${ }^{6}$ The score for each paw was graded from 0 to 5,0 representing no inflammation, the paw being indistinguishable from that of the control, and 5 representing a paw which was severely oedematous and erythematous. All rats used in this study had an arthritic score greater than 3 for both hind and fore paws.

LIPOSOME PREPARATION

Negative liposomes were prepared in a molar ratio of 7:2:1 of egg phosphatidylcholine:cholesterol: phosphatidic acid. The total lipid mass used was 20 
mg. The original method of Bangham et al ${ }^{1}$ was modified as described below.

The lipids were dissolved in chloroform and dried onto a glass vessel wall under a stream of nitrogen gas. Multilamellar vesicles were formed by the addition of $2 \mathrm{ml}$ of $0.9 \%$ saline to the lipid film and then shaking the mixture. A reduction in the size of the liposomes was accomplished by probe sonication using a $150 \mathrm{~mW}$ Soniprep (MSE Scientific Instruments, UK) with a $10 \mathrm{~mm}$ probe. Small unilamellar vesicles were produced by two $6 \mu \mathrm{m}$ amplitude bursts for five minutes, followed by two $10 \mu \mathrm{m}$ bursts for five minutes; the sample was immersed in an ice bath throughout all the sonication steps. Larger liposomes were prepared in the same manner, but the sonication times were shorter. Titanium fragments from the probe were removed from the small unilamellar vesicle preparations by centrifugation for 20 minutes at $17000 \mathrm{~g}$. The four liposome preparations used in this study were $67 \mathrm{~nm}, 95 \mathrm{~nm}$, $200 \mathrm{~nm}$, and $1150 \mathrm{~nm}$ in diameter, their size being determined by photon correlation spectroscopy (Malvern, England).

LIPOSOME RADIOLABELLING TECHNIQUES Radiolabelling of liposomes with ${ }^{125} \mathrm{I}$ egg phosphatidylcholine

The method of Arrowsmith et al $^{7}$ was followed, with the adaptations described by Love et al. ${ }^{8}{ }^{125} \mathrm{I}$ labelled egg phosphatidylcholine was incorporated into the liposome by adding it to the unlabelled lipid dissolved in solvent at the initial stage of preparation.

Radiolabelling of liposomes with ${ }^{99 m} T c$

Preformed liposomes were radiolabelled with ${ }^{99 \mathrm{~m}} \mathrm{Tc}$ using the method described by Richardson et al ${ }^{9}$; modifications to this method were as described by Love et al. ${ }^{8}$

PREPARATION OF ${ }^{99 m} \mathrm{Tc}^{\mathrm{S}} \mathrm{S} \mathrm{Cl}_{2}$ COLLOID AND FREE ${ }^{99 m}$ TC PERTECHNETATE

The ${ }^{99 \mathrm{~m}} \mathrm{Tc}$ tin colloid was produced by adding 40 $\mathrm{MBq}$ of ${ }^{99 \mathrm{~m}} \mathrm{Tc}$ pertechnetate to $1 \mathrm{ml}$ of freshly prepared $\mathrm{SnCl}_{2}$ in deoxygenated water at a concentration of $6.7 \mathrm{mg} / \mathrm{ml}$. All the ${ }^{99 \mathrm{~m}}$ Tc pertechnetate was bound to the tin colloid and appeared in the void volume fractions of a Sephadex G-25 column.

To assess distribution of the free isotope the ${ }^{99 \mathrm{~m}} \mathrm{Tc}$ pertechnetate was used directly from the technetium generator.

ASSESSMENT OF THE STABILITY IN VIVO OF $99 \mathrm{~m}$ T C LABELLED NEGATIVE LIPOSOMES Blood clearance studies of liposomes labelled with ${ }^{99 \mathrm{~m}} \mathrm{Tc} /{ }^{125} \mathrm{I}$ egg phosphatidylcholine were carried out in normal female Sprague-Dawley rats weighing approximately $200 \mathrm{~g}$. Three rats were injected intravenously with $25 \mathrm{mg} / \mathrm{kg}$ of $95 \mathrm{~nm}$, dual labelled negative liposomes and their clearance determined by repeated sampling from the tail vein over four hours. An LKB Compugamma counter was used to count both the ${ }^{99 \mathrm{~m}} \mathrm{Tc}$ and ${ }^{125} \mathrm{I}$, and appropriate corrections were made for the decay of the radioisotopes and for the crossover between two channels when two isotopes were used in the same animal.

A similar clearance procedure was carried out in normal rats to study the fate of free ${ }^{99 \mathrm{~m}} \mathrm{Tc}$ and ${ }^{99 m} \mathrm{Tc}-\mathrm{SnCl}_{2}$ colloid in the circulation as these were considered to be possible contaminants of the radiolabelled liposome preparations.

TISSUE DISTRIBUTION OF DIFFERENT SIZED $99 \mathrm{~m}$ T C LABELLED NEGATIVE LIPOSOMES IN

CONTROL AND ARTHRITIC RATS

Control and arthritic rats (three rats per group) were used for each of the four different sized liposome preparations $(25 \mathrm{mg} / \mathrm{kg}, 4 \mathrm{MBq})$, free ${ }^{99 \mathrm{~m}} \mathrm{Tc}(4$ $\mathrm{MBq} / \mathrm{rat})$, and ${ }^{99 \mathrm{~m}} \mathrm{Tc}-\mathrm{SnCl}_{2}$ colloid $(5 \mathrm{mg} / \mathrm{kg}, 4 \stackrel{2}{2}$ $\mathrm{MBq})$. These were injected intravenously via the tail $\overrightarrow{0}$ vein, but a small aliquot of each was retained to serve as a standard. At the same time each anima received $100 \mu$ l of a $50 \%$ suspension of ${ }^{51} \mathrm{Cr}$ labelle $(370 \mathrm{kBq})$ rat erythrocytes to serve as a blood poot marker. ${ }^{10}$ All the rats were bled at regular intervals from the tail vein during the experiment so that the clearance of each of the preparations could be determined. After $80 \%$ of each preparation had been cleared from the circulation the rats were killed and the relevant tissues, including all four paws, were removed. The amount of ${ }^{99 \mathrm{~m}} \mathrm{Tc}$ and ${ }^{51} \mathrm{Cr}$ present in the tissues was measured in an LKB Compugamma counter, with the appropriate corrections made for crossover between the two channels. Specific liposome accumulation in various tissues was calculated by applying the following equation: Specific accumulation $={ }^{99 \mathrm{~m}} \mathrm{Tc}$ tissue $-\left[{ }^{51} \mathrm{Cr}\right.$ tissue $\left.\times \frac{{ }^{99 \mathrm{~m}} \mathrm{Tc} \text { blood }}{{ }^{51} \mathrm{Cr} \text { blood }}\right]$ Results

Figure 1 shows the blood clearance profile of the $N$ dual labelled, $95 \mathrm{~nm}$, negative liposomes in normal rats. There was no difference in the rate at which the ${ }^{99 \mathrm{~m}}$ Tc liposome surface marker and the ${ }^{125} \mathrm{I}$ labelled egg phosphatidylcholine integral liposome membrane marker were removed from the circulation. The clearance of both free ${ }^{99 \mathrm{~m}} \mathrm{Tc}$ and ${ }^{99 \mathrm{~m}} \mathrm{Tc}-\mathrm{SnCl}_{2}{ }_{7}$ colloid, however, was much faster than the lipo- o somes, with more than $80 \%$ and $98 \%$ respectively being cleared in the first 15 minutes after injection.

Figure 2 also shows that there was no difference in 


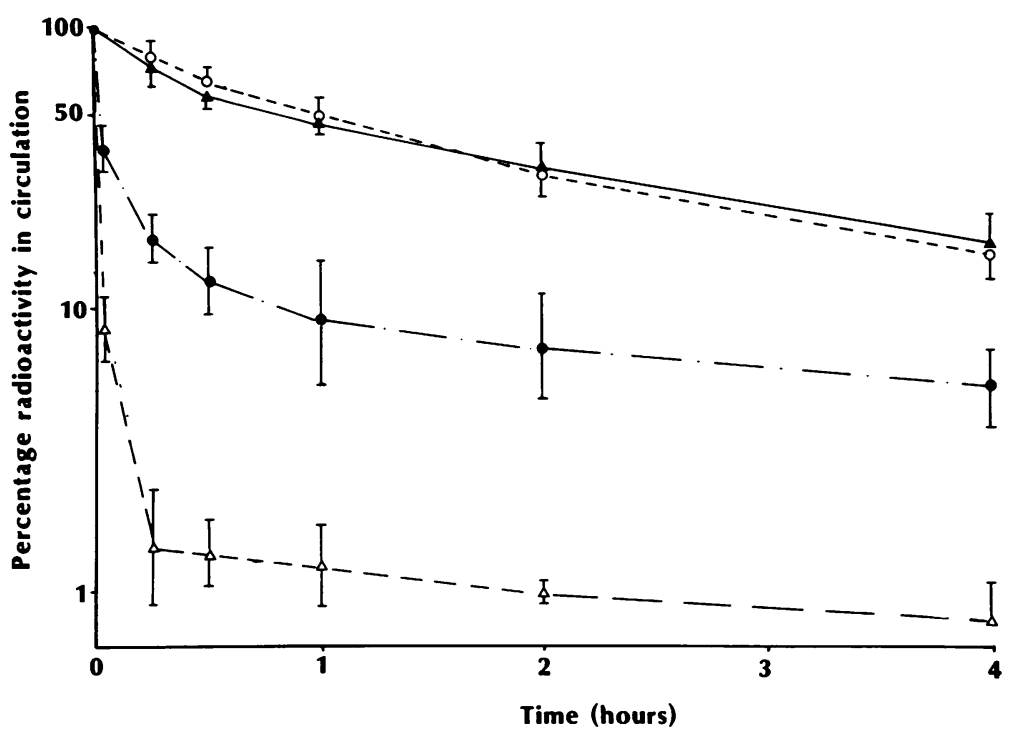

Fig. 1 Clearance from the circulation of ${ }^{99 m} \mathrm{Tc}^{125}$ I labelled $(\boldsymbol{\Lambda}, \mathrm{O}), 95 \mathrm{~nm}$, negative liposomes, free ${ }^{99 m} \mathrm{Tc}(\mathbf{O})$, and ${ }^{99 m} \mathrm{Tc}_{\mathrm{S}} \mathrm{SnCl}_{2}$ colloid $(\triangle)$ in normal rats (three per group, mean $(S D))$.

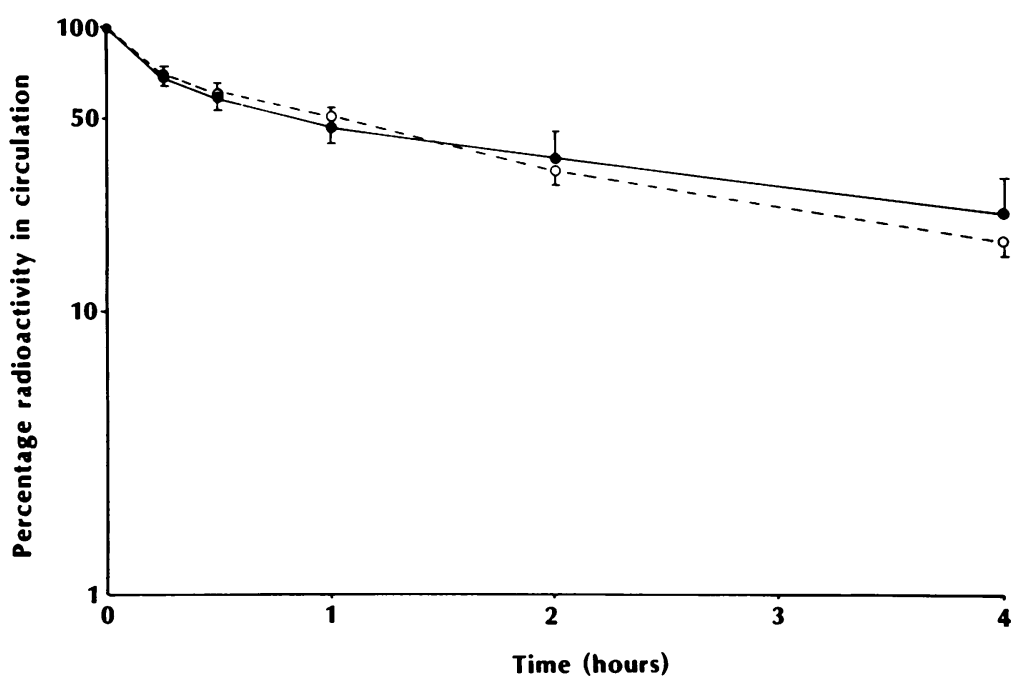

Fig. 2 Clearance from the circulation of ${ }^{99 m}$ Tc labelled, $95 \mathrm{~nm}$, negative liposomes in normal rats $(0)$ and rats with adjuvant arthritis $(O)$ (three per group, mean $(S D))$.

the clearance of ${ }^{99 \mathrm{~m}} \mathrm{Tc}$ labelled, $95 \mathrm{~nm}$, negative liposomes from the circulation of normal and arthritic animals; this finding was also applicable for the other three liposome preparations tested. The removal of liposomes from the circulation was influenced by their size, with the larger liposomes being removed at a faster rate (Fig. 3). The half lives of the four preparations were 50 minutes for the 67 $\mathrm{nm}$ and $95 \mathrm{~nm}$ liposomes, 28 minutes for the $200 \mathrm{~nm}$ liposomes, and eight minutes for the $1150 \mathrm{~nm}$ liposomes.
The distribution of liposome bound technetium was examined both in the arthritic and control animals. Table 1 shows that the total specific accumulation (expressed as a percentage of the injected dose) in the liver, spleen, heart, lungs, and kidneys was comparable in both control and arthritic animals for the $95 \mathrm{~nm}$ and $1150 \mathrm{~nm}$ liposomes; this was also true for the other two liposome preparations. The difference between small unilamellar vesicle and multilamellar vesicle accumulation in inflamed and control paws was highly significant, 


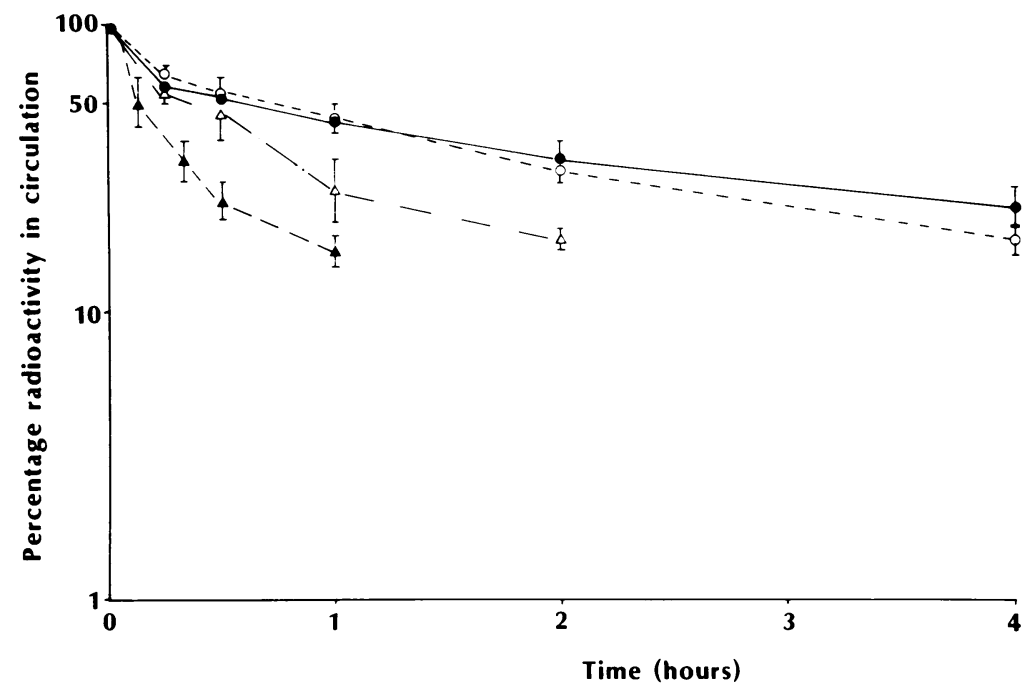

Fig. 3 Clearance from the circulation of ${ }^{99 m}$ Tc labelled, $67 \mathrm{~nm}(\Theta), 95 \mathrm{~nm}(\bigcirc), 200 \mathrm{~nm}$ $(\triangle)$, and $1150 \mathrm{~nm}(\mathbf{\Delta})$, negative liposomes in normal/arthritic rats (six per group, mean $(S D)$ ).

Table 1 Total percentage of specific accumulation for the $95 \mathrm{~nm}$ and $1150 \mathrm{~nm}$ liposome preparations, free ${ }^{99 m} \mathrm{Tc}$, and ${ }^{99 m} \mathrm{Tc}_{-} \mathrm{SnCl} \mathrm{Cl}_{2}$ colloid in control and arthritic rat tissues after $80 \%$ clearance from the circulation. Values are means (SD) with three rats per group

\begin{tabular}{|c|c|c|c|c|c|c|c|}
\hline & Liver & Spleen & Heart & Kidneys & Lungs & $\begin{array}{l}\text { Hind } \\
\text { paws }\end{array}$ & $\begin{array}{l}\text { Fore } \\
\text { paws }\end{array}$ \\
\hline \multicolumn{8}{|c|}{$95 \mathrm{~nm}$ liposomes } \\
\hline Control & $33.9(1.7)$ & $6 \cdot 37(1.23)$ & $0.09(0.01)$ & $6.57(0.32)$ & $0.49(0.09)$ & $0.48(0.04)$ & $0.20(0.04)$ \\
\hline Arthritic & $30 \cdot 1(10 \cdot 2)$ & $5.77(1.26)$ & $0.09(0.02)$ & $6 \cdot 13(0.53)$ & $0.44(0.05)$ & $3.7(1.42)$ & $1.62(0.66)$ \\
\hline \multicolumn{8}{|c|}{$1150 \mathrm{~nm}$ liposomes } \\
\hline Control & $45 \cdot 3(5 \cdot 8)$ & $6.67(0.33)$ & $0.04(0.005)$ & $0.39(0.05)$ & $0 \cdot 12(0 \cdot 02)$ & $0.05(0.01)$ & $0.03(0.004)$ \\
\hline Arthritic & $48 \cdot 5(13 \cdot 1)$ & $6 \cdot 36(2 \cdot 5)$ & $0.06(0.03)$ & $0.25(0.22)$ & $0 \cdot 18(0.09)$ & $0.42(0.07)$ & $0 \cdot 19(0 \cdot 01)$ \\
\hline \multicolumn{8}{|l|}{ Free ${ }^{99 \mathrm{~m}} \mathrm{Tc}$} \\
\hline Control & $1.73(0 \cdot 05)$ & $0.82(0 \cdot 2)$ & $0.06(0.01)$ & $1 \cdot 35(0.06)$ & $0 \cdot 25(0 \cdot 0)$ & $1.06(0.38)$ & $0 \cdot 31(0 \cdot 02)$ \\
\hline $\begin{array}{c}\text { Arthritic } \\
\text { 999me-SnCl }\end{array}$ & $2.86(0.82)$ & $0.97(1.53)$ & $0 \cdot 15(0 \cdot 11)$ & ${ }^{99}{ }^{\mathrm{m}} \mathrm{Tc}-\mathrm{SnCl}_{2}$ colloid & $0.45(0.08)$ & $4 \cdot 16(1.78)$ & $2 \cdot 14(1 \cdot 1)$ \\
\hline Control & $45 \cdot 7(4 \cdot 6)$ & $2 \cdot 15(0 \cdot 2)$ & $0.01(0.004)$ & $0.17(0.03)$ & $0.27(0.13)$ & $0.06(0.02)$ & $0.1 \quad(0.02)$ \\
\hline Arthritic & $53 \cdot 2(7 \cdot 4)$ & $2.72(0.04)$ & $0.01(0.007)$ & $0.12(0.02)$ & $0.41(0.15)$ & $0.024(0.004)$ & $0.006(0.002)$ \\
\hline
\end{tabular}

Within group comparison of accumulation between control and arthritic animals gives $p>0 \cdot 1$ for all tissues except for hind and fore paws. where $\mathrm{p}<0.001$ using Student's $t$ test.

however; $5 \cdot 3 \%$ of the $95 \mathrm{~nm}$ liposomes accumulated in inflamed paws, whereas only $0.6 \%$ of the $1150 \mathrm{~nm}$ liposomes accumulated in the inflamed paws. In control paws $0.68 \%$ and $0.08 \%$ of the $95 \mathrm{~nm}$ and $1150 \mathrm{~nm}$ liposomes accumulated respectively. There were also interesting differences between the distribution of free ${ }^{99 \mathrm{~m}} \mathrm{Tc}$ and ${ }^{99 \mathrm{~m}} \mathrm{Tc}-\mathrm{SnCl}_{2}$ colloid. Uptake in the reticuloendothelial system occurred only with the colloid, whereas accumulation in inflamed tissue was only seen with the free isotope $(6 \cdot 3 \%)$. There was, however, more free isotope $(1.37 \%)$ in the control paws. When specific uptake was expressed per gram of tissue differences between the liposome accumulation in the control and inflamed tissue became clear for all preparations (Fig. 4, Table 2).

More free ${ }^{99 \mathrm{~m}} \mathrm{Tc}$ was found in control paw tissue, but there was no difference between the accumulation of free ${ }^{99 \mathrm{~m}} \mathrm{Tc}$ and small unilamellar vesicle bound activity in the inflamed paws. Colloid accumulation in both control and inflamed tissue was negligible.

\section{Discussion}

One of the important factors regulating the use of 


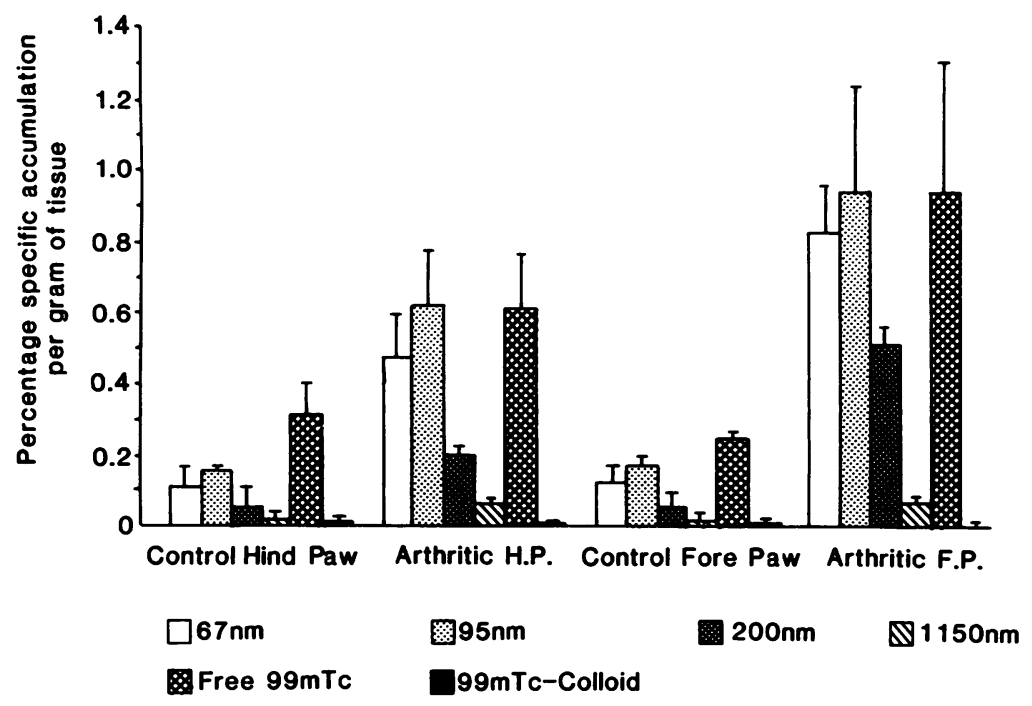

Fig. 4 Specific accumulation per gram of tissue of four liposome preparations, free ${ }^{99 m} T c$, and ${ }^{99 m} \mathrm{Tc}-\mathrm{SnCl}{ }_{2}$ colloid in normal and arthritic hind and fore paws (mean $(S D))$.

Table 2 Student's test of significance between preparations

\begin{tabular}{|c|c|c|}
\hline \multirow[t]{2}{*}{ Preparations tested } & \multicolumn{2}{|l|}{ p Values } \\
\hline & $\begin{array}{l}\text { Arthritic } \\
\text { paws }\end{array}$ & $\begin{array}{l}\text { Control } \\
\text { paws }\end{array}$ \\
\hline $67 \mathrm{~nm} v 95 \mathrm{~nm}$ & $>0.1$ & $>0.1$ \\
\hline $67 \mathrm{~nm} \vee 200 \mathrm{~nm}$ & $<0.01$ & $<0.001$ \\
\hline $67 \mathrm{~nm} v 1150 \mathrm{~nm}$ & $<0.01$ & $<0.001$ \\
\hline $95 \mathrm{~nm} v 200 \mathrm{~nm}$ & $<0.01$ & $<0.001$ \\
\hline $95 \mathrm{~nm} v 1150 \mathrm{~nm}$ & $<0.01$ & $<0.001$ \\
\hline $200 \mathrm{~nm} v 1150 \mathrm{~nm}$ & $<0.01$ & $<0.001$ \\
\hline $67 \mathrm{~nm} v$ free ${ }^{99 m} \mathrm{Tc}$ & $>0 \cdot 1$ & $<0.01$ \\
\hline $95 \mathrm{~nm} v$ free ${ }^{99 m} \mathrm{Tc}$ & $>0.5$ & $<0.01$ \\
\hline $200 \mathrm{~nm} v$ free ${ }^{99 m} \mathrm{Tc}$ & $<0.001$ & $<0.001$ \\
\hline $1150 \mathrm{~nm} v$ free ${ }^{99 \mathrm{~m}} \mathrm{Tc}$ & $<0.001$ & $<0.001$ \\
\hline $\begin{array}{l}1150 \mathrm{~nm} \\
\text { colloid }\end{array}{ }^{99 \mathrm{~m}} \mathrm{Tc}-\mathrm{SnCl}_{2}$ & $<0.001$ & $>0.5$ \\
\hline
\end{tabular}

All other preparations $v{ }^{99 \mathrm{~m}} \mathrm{Tc}-\mathrm{SnCl}_{2}$ colloid, $\mathrm{p}<0 \cdot 001$.

radiolabelled liposomes in vivo is the stability of the isotope on the liposome surface. The results we obtained with the dual labelled liposomes were important in that they clearly showed that the ${ }^{99 \mathrm{~m}} \mathrm{Tc}$ radiolabel remained attached to the liposome surface in vivo. Therefore, changes in the concentration of the radiolabel reflect the clearance of the liposome from the circulation. We have shown that the surface charge of the liposome influences the stability of the isotope in vivo. ${ }^{8}$ Positively charged liposomes lose most of the ${ }^{99 \mathrm{~m}} \mathrm{Tc}$ from their surface within 15 minutes of injection. A similar phen- omenon occurs with neutral liposomes, but the rate of ${ }^{99 \mathrm{~m}} \mathrm{Tc}$ loss from the surface is much slower. The isotope stability was uninfluenced by serological changes associated with inflammation. Increases in the acute phase protein $\alpha_{1}$ macroglobulin, which binds to liposomes, ${ }^{11}$ had no detectable effect on the liposome radiolabel.

The clearance and distribution of the ${ }^{99 \mathrm{~m}} \mathrm{Tc}-\mathrm{SnCl}_{2}$ colloid was examined because some colloid could have been transferred with the radiolabelled liposomes, even though the conditions used in the labelling technique (less than $0.3 \mathrm{mg}$ of $\mathrm{SnCl}_{2}$ ) are claimed to prevent colloid formation. ${ }^{12}$ Its large size and extremely rapid clearance in vivo prevented any accumulation in inflamed tissue. The removal of free ${ }^{99} \mathrm{~m}$ Tc was also extremely rapid. Had any significant loss of the isotope occurred from the liposome surface we would have observed a dissociation between the clearance of ${ }^{125} \mathrm{I}$ and ${ }^{99 \mathrm{~m}} \mathrm{Tc}$, and a reduction in the accumulation of the isotope in the liver and spleen.

The primary sites of liposome accumulation were the liver and spleen, and the uptake in these organs did not differ between the control and arthritic animals. In inflamed tissues, however, there were striking increases in liposome accumulation which were also related to liposome size. Up to $5.3 \%$ of the total quantity of small unilamellar vesicles injected accumulated in all four inflamed paws, whereas only $0.6 \%$ of the $1150 \mathrm{~nm}$ liposomes was found in inflamed tissue. Free ${ }^{99 \mathrm{~m}} \mathrm{Tc}$ also identified inflamed tissue $(6 \cdot 3 \%$ in all paws), but its failure to accumulate in the liver and spleen suggested that its accumulation in inflammatory tissue was due to 
extravascular diffusion, a view reinforced by the higher total percentage accumulation seen in noninflamed tissue. When the results were expressed per gram of tissue, a factor which takes into account the much larger size of inflamed paws, a four- to 10-fold increase in liposome accumulation was observed in the inflamed paws compared with the control paws.

A change in the permeability of capillaries in inflamed tissue is well recognised, ${ }^{13}$ and it is likely that the accumulation of liposomes reflects the transcapillary passage of these vesicles. Their size is clearly important, and a change from $95 \mathrm{~nm}$ to 200 $\mathrm{nm}$ begins to influence their accumulation, though it is unclear whether this is entirely due to the size of the liposome or to their faster removal from the circulation to the reticuloendothelial system. Transcapillary passage of small unilamellar vesicles is known to occur into non-inflamed tissues which have a sinusoidal capillary network, but at sites such as the lung, where capillary junctions are intact, phagocytosis of liposomes by macrophages with subsequent migration into the alveoli has been recorded. ${ }^{14}$ It is not known at present whether this is a mechanism which contributes to the deposition of liposomes in the inflamed tissue, though in both rheumatoid arthritis and adjuvant induced arthritis numerous phagocytic cells are known to be present. $^{1516}$

The $95 \mathrm{~nm}$ liposomes used in the rat were the same composition and size as those injected into patients with rheumatoid arthritis. ${ }^{3}$ The results obtained in the rat model support the view that the scintigraphs taken of the joints of patients with rheumatoid arthritis reflect the tissue distribution of the liposome, though at present their partitioning within the synovium - that is, within the extravascular space or within phagocytic cells, is uncertain. Studies in which scintigraphy was carried out before and after joint aspiration have established that positive scintigraphs are not produced by the accumulation of liposomes in synovial fluid. ${ }^{3}$

The localisation of over $5 \%$ of the small unilamellar vesicles into inflammatory tissue in the rat is of potential interest. This degree of localisation may account for the much greater potency (10-fold increase) of liposome encapsulated cortisol palmitate in reducing the amount of inflammation associated with the injection of carrageenan into the rat paw. ${ }^{17}$

In conclusion, our studies have established that negative liposomes accumulate in inflamed tissue to a greater extent than in control tissue and that liposome size plays an important part in regulating the degree of uptake. Further studies are required to? determine the optimal liposome composition and charge to maximise their accumulation in inflamed tissues.

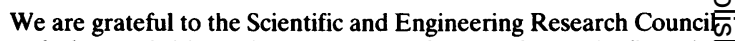
and the Arthritis and Rheumatism Council for their financiaP support.

\section{References}

1 Bangham A D, Standish M M, Watkins J C. The action of steroids and streptolysin $\mathrm{S}$ on the permeability of phospholipidw structures to cations. J Mol Biol 1965; 13: 238-52.

2 Morgan J R, Williams K E, Davies R L, Leach K, Thomson $M_{\text {गे }}^{2}$ Williams L A. Localisation of experimental staphylococca? abscesses by $99 \mathrm{~m}$-Tc-technetium-labelled liposomes. J Med5o Microbiol 1981; 14: 213-7.

3 Williams B D, O'Sullivan M M, Saggu G S, Williams K E Williams L A, Morgan J R. Synovial accumulation of tech netium labelled liposomes in rheumatoid arthritis. Ann Rheum음 Dis 1987; 46: 314-8.

4 Martin G P, Kellaway I W, Marriot C. The solubilisation of progesterone by mixed bile salt-phospholipid solutions. Chem Phys Lipids 1978; 22: 22-5.

5 Pearson C M. Development of arthritis, periarthritis and

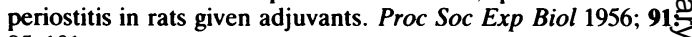
95-101.

6 Trentham D E, Townes A S, Kang A H. Autoimmunity to tæe II collagen: an experimental model of arthritis. J Exp Med 187 146: 857-68.

7 Arrowsmith M, Hadgraft J, Kellaway I W. The in vivo rel6a्s. of cortisone esters from liposomes, and the intramusctita clearance of liposomes. International Journal of Pharmaceutic? 1984: 20: $347-55$

8 Love W G, Amos N, Williams B D, Kellaway I W. Effect of्? liposome surface charge on the stability of $99 \mathrm{~m}$-technetium radiolabelled liposomes. Journal of Microencapsulation (in press).

9 Richardson V R, Jeyasingh K, Jewkes R F, Ryman B E Tattersall M H. Properties of ${ }^{99 \mathrm{~m}} \mathrm{Tc}$-labelled liposomes in normal, and tumour-bearing rats. Biochem Soc Trans 1977; 5? 290-2.

10 Gray S J, Sterling K. The tagging of red cells and plasma proteins with radioactive chromium. J Clin Invest 1950; 29! 1604-13.

11 Black C D, Gregoriadis G. Interaction of liposomes with blood plasma proteins. Biochem Soc Trans 1976; 4: 253-6.

12 Farr S J, Kellaway I W, Parry-Jones D R, Woolfrey S G₹ $99 \mathrm{mTechnetium}$ as a marker of liposome deposition and clearo ance in the human lung. International Journal of Pharmaceutics 1985; 26: 303-16.

13 Kushner I, Somerville J A. Permeability of human synovia membrane to plasma proteins: relationship to molecular siz̄̄ and inflammation. Arthritis Rheum 1971; 14: 560-70.

14 Poste G, Bucana C, Fidler I J. Analysis of the fate of systemically administered liposomes and implications for theif use in drug delivery. Cancer Res 1982; 42: 141-9.

15 Zvaifler $\mathrm{N} J$. The immunopathology of joint inflammation in rheumatoid arthritis. Adv Immunol 1973; 16: 265-336.

16 Mohr W, Wild A, Wolf H P. Role of polymorphs in inflammatory cartilage in adjuvant arthritis. Ann Rheum DiE 1981; 40: 171-6.

17 Cleland L G, Allen T M. Liposomes as carriers of anti= inflammatory drugs for systemic use. Aust NZ J Med 1980; 10ळ̄ 269-70. 